\title{
Occurrence of Cryptosporidium spp. in wild animals living in the Cascavel city park, Paraná, Brazil
}

\section{Ocorrência de Cryptosporidium spp. em animais silvestres do Parque municipal de Cascavel, Paraná, Brasil}

\author{
Alessandra Snak ${ }^{1 *}$; Felipe Gustavo Garcia ${ }^{2}$; Luis Eduardo da Silveira Delgado; \\ Silvia Cristina Osaki ${ }^{4}$
}

\begin{abstract}
Digestive and respiratory tracts parasite's protozoan, Cryptosporidium spp. now-a-days is a major zoonotic agent, it causes self-limiting diarrhea, remaining in the body passively until the moment immune system decreases, leading to an increase in its multiplication in the mucosa and appearance of clinical signs. As there are few studies on cryptosporidiosis in wild free-living and captive animals, especially in Brazil, this study aimed to identify the presence of Cryptosporidium spp. in feces of captive animals in Cascavel, PR Municipal Zoo. Between 2011 and 2012 there have been four collections of bird feces and five mammalian feces totaling 65 and 118 samples respectively. Samples were sent to the laboratory of Veterinary Parasitology of Federal University of Parana. The feces were diluted, centrifuged and the pellets were used to make blades which were stained by the Ziehl-Neelsen modified method and observed under a microscope with 1000X magnification. Then the blades containing the oocysts were observed under a capture microscope, where they were measured. Mammals showed $49.15 \%$ and birds $44.61 \%$ of positivity. Oocysts' sizes ranged from $3,54 \mu \mathrm{m}$ to $5,81 \mu \mathrm{m}$ with an average of $4,32 \mu \mathrm{m}$ for birds and $3,11 \mu \mathrm{m}$ to $5,60 \mu \mathrm{m}$ averaging $4,63 \mu \mathrm{m}$ to mammals. As of yet, there isn't effective treatment against this parasite and considering that it's a zoonotic disease, preventive measures should be taken to prevent transmission to humans.
\end{abstract}

Key words: Cryptosporidium, wild animals, Ziehl-Neelsen, zoonosis

\section{Resumo}

Protozoário que parasita o trato digestório e respiratório dos animais, o Cryptosporidium spp. é um importante agente zoonótico da atualidade, responsável por causar diarreia auto limitante, permanecendo no organismo de forma passiva até o momento em que há uma queda da imunidade, levando a um aumento na sua multiplicação na mucosa e aparecimento de sinais clínicos. Como há poucos estudos sobre a criptosporidiose em animais silvestres de vida livre e de cativeiro, especialmente no Brasil, esse trabalho teve como objetivo realizar uma pesquisa para identificar a presença de oocistos de Cryptosporidium spp. em fezes dos animais cativos no Zoológico Municipal de Cascavel, Paraná. No período de 2011 e 2012 foram realizadas quatro coletas de fezes de aves e cinco de fezes de mamíferos totalizando 65 e 118 amostras respectivamente. As amostras foram enviadas ao laboratório de parasitologia veterinária da Universidade Federal do Paraná, Setor Palotina. As fezes foram diluídas, centrifugadas e os sedimentos foram utilizados para a confecção de lâminas, que foram coradas pelo

\footnotetext{
${ }^{1}$ Médica Veterinária, Universidade Federal do Paraná, UFPR, Palotina, PR, Brasil. E-mail: alessandra.snak@hotmail.com

2 Discente do Curso de Graduação em Medicina Veterinária, UFPR, Palotina, PR, Brasil. E-mail: felipedo402@gmail.com

${ }^{3}$ Médico Veterinário, Prefeitura Municipal de Cascavel, Cascavel, PR, Brasil. E-mail: dadodelgado@gmail.com

${ }^{4}$ Prof $^{\mathrm{a}} \mathrm{Dr}^{\mathrm{a}}$, UFPR, Palotina PR, Brasil. E-mail: silvia_cristinao@yahoo.com.br

* Author for correspondence
} 
método de Ziehl-Neelsen modificado e observadas em microscópio com aumento 1000X. Em seguida as lâminas contendo os oocistos foram observadas em microscópio de captura, onde os mesmos foram mensurados. Os mamíferos apresentaram $49,15 \%$ de positividade e as aves $44,61 \%$ das amostras positivas. O tamanho dos oocistos variou de $3,54 \mu \mathrm{m}$ a $5,81 \mu \mathrm{m}$ com uma média de $4,32 \mu \mathrm{m}$ para aves e de $3,11 \mu \mathrm{m}$ a $5,60 \mu \mathrm{m}$ com média de $4,63 \mu \mathrm{m}$ para mamíferos. Como ainda não há tratamento eficaz para esse parasito e considerando que se trata de uma zoonose, medidas preventivas devem ser tomadas para evitar a transmissão para humanos.

Palavras-chave: Cryptosporidium, animais silvestres, Ziehl-Neelsen, zoonoses

\section{Introduction}

Cryptosporidium spp. are protozoa that parasitize humans, domestic and wild animals, mainly inhabiting the gastrointestinal and respiratory tract (SAVIOLI et al., 2006; FAYER, 2010; PEREIRA et al., 2010; SANTIN, 2013). Currently, there are about 26 species of Cryptosporidium spp. accepted (ICZN) and 40 described genotypes infecting humans and / or animals (RYAN et al., 2014).

The main species with zoonotic characteristics are: C. hominis, C. parvum, C. canis, C. felis, $C$. meleagridis and more recently species $C$. ubiquitum, wherein the latter two species affect wild and domestic birds and deer respectively (LI et al., 2014).

Currently a large number of zoos, conservation parks and centers of wildlife rehabilitation have shown concern regarding the presence and degree of animals' contamination by parasites. The zoo environment, due to the concentration of different animal species in restricted spaces, associated with the stress of captivity and direct contact with the human being, becomes susceptible to infection by Cryptosporidium spp. (LUDWIG; MARQUES, 2011).

This disease may occur without the animal or person exhibit clinical signs, which enables to occur the environmental contamination without preventive measures (SHI et al., 2010), but in immunodeficient individuals, Cryptosporidium spp. is causing enterocolitis, diarrhea and cholangiopathy and can lead to death (XIAO et al., 2004; ARROWOOD; STERLIN, 1989; ABRAHAMSEN et al., 2004;
LALLO; BONDAN, 2009). The disease's diagnosis in environments such as refuges and zoos, where there are large numbers of animals in constant stress and contact with humans periodically, it is extremely important for animal health, and it is also especially important to human health.

\section{Material and Methods}

This work was carried out in the Municipal Park Danilo Galafassi, known as Cascavel Municipal Zoo, which has an area of 17,91ha, and is part of the Municipal Park Paulo Gorski (Municipal Lake and Zoo Complex) with 111,26ha (Figure 1).

The Zoo currently has about 340 animals of about 68 species, which were acquired by barter of animals with other institutions, acquisitions of other zoos, donations overseen by Brazilian Institute of Environment and Renewable Natural Resource (BIERNR), births at the zoo itself and seizure of animals held by BIERNR and Forest Police. The zoo has about 37 species of birds, 23 mammals' species and eight species of reptiles (PORTAL DO MUNICÍPIO DE CASCAVEL, 2015).

During the period of July 2011 to June 2012, five collections of mammalian feces were made, totaling 118 samples in 33 enclosures. Most of the carnivores were in individual enclosures, but the omnivores' was collective. In case of the birds, four collects were made, totalizing 65 samples in 20 enclosures, being all of these collectives.

Samples were collected from the ground avoiding contamination straw, sawdust, mud or other foreign material, being placed in clean containers and kept 
under cooling, after that, about $5 \mathrm{~g}$ of feces were diluted in $40 \mathrm{ml}$ of water and then passed through a tea strainer with gauze into another container, to the solid particles be removed. Then a small sample of the liquid was centrifuged for two minutes at $2.500 \mathrm{rpm}$, discarding the supernatant. Slides were prepared using the pellet.
After the blades were dried, the modified Ziehl-Neelsen staining method was performed (ORTOLANI, 2000). The blades were examined under a light microscope with magnification of 1000 times using the immersion objective and later on the oocysts were measured in capture microscope.

Figure 1. Municipal Park Paulo Gorski in Cascavel, Paraná.

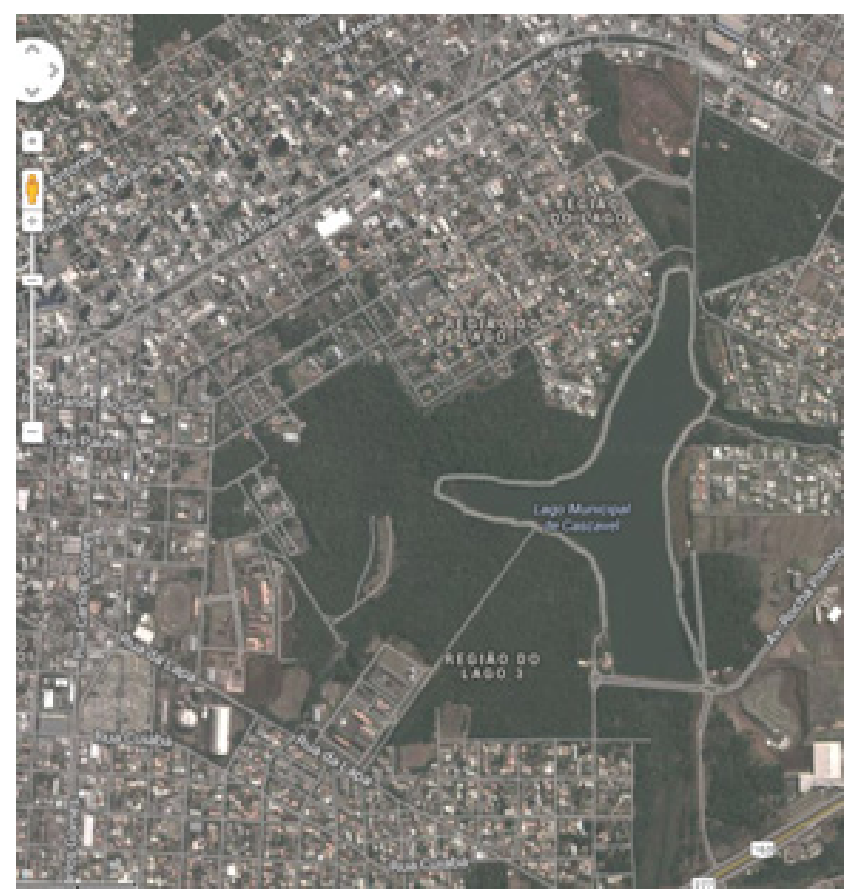

Source: Google maps (2015).

\section{Results and Discussion}

Table 1 summarizes results found for mammals. Out of the 118 analyzed samples from enclosures, $58(49.15 \%)$ were positive for Cryptosporidium spp., that makes a high percentage when compared to other studies that investigated the presence of this parasite in several species of wild mammals, such as primates, sika deer, panda, wild boar, which found a positivity percentage of $3 ; 1.6 ; 15.6 ; 5.4$ respectively (DU et al., 2015; WANG et al., 2008, WANG et al., 2015; ATWILL et al., 1997).

Three species of mammals had all negative results: bush dog, lion and jaguar, since the animal with the highest rate of infection was collared peccary with $88.88 \%$, followed by cambuta deer and brocket deer with $75 \%$. These results may be due to feeding type, once that the bush dog, lion and jaguar are carnivores and the collared peccary, cambuta deer and brocket deer are herbivores, facilitating the ingestion of oocysts in the soil and the vegetation.

The oocysts measured between $3.11 \mu \mathrm{m}$ and $5.60 \mu \mathrm{m}$, with an average size of $4.63 \mu \mathrm{m}$ (Figure 2A), similar results found by Xiao et al. (2002) in which the oocysts varied from $3 \mu \mathrm{m}$ to $8 \mu \mathrm{min}$ size. 
Primates showed high positivity. Out of the total of 31 analyzed stool samples, 18 (58.06\%) were positive, results much higher than those found by other authors in different parts of the world, ranging from 0.5 to $27 \%$ (SAK et al., 2013;
SALYER et al., 2012; PARSONS et al., 2015; EKANAYAKE et al., 2006). These authors claim that environmental changes caused by man and the use of these means by humans and animals provide a transmission of parasitic infection between wild and domestic animals and man.

Table 1. Results of mammals'samples of Municipal Park Danilo Galafassi processed by the Ziehl-Neelsen method.

\begin{tabular}{|c|c|c|c|c|c|}
\hline Scientific name & Commom name & $\begin{array}{l}\text { Number of } \\
\text { enclosures }\end{array}$ & Samples & Pos. & \% Pos. \\
\hline Panthera onca & Jaguar & 1 & 2 & 0 & 0 \\
\hline Panthera leo & Lion & 5 & 14 & 0 & 0 \\
\hline Puma concolor & Cougar & 3 & 9 & 6 & 66.7 \\
\hline Puma yagouaroundi & Jaguarundi & 2 & 8 & 3 & 37.5 \\
\hline Leopardus tigrinus & Oncilla & 2 & 6 & 3 & 50 \\
\hline Leopardus pardalis & Ocelot & 1 & 3 & 1 & 33.3 \\
\hline Panthera tigres & Tiger & 1 & 3 & 1 & 33.3 \\
\hline Cerdocyon thous & Crab-eating fox & 1 & 2 & 0 & 0 \\
\hline Eyra barbara & Tayra & 1 & 5 & 2 & 40.0 \\
\hline Alouatta caraya & Howler monkey & 1 & 5 & 1 & 20.0 \\
\hline Ateles paniscus & Spider monkey & 1 & 5 & 3 & 60.0 \\
\hline Cebus sp. & Capuchin monkey & 4 & 17 & 12 & 70.6 \\
\hline Callithrix sp. & Marmoset & 1 & 4 & 2 & 50.0 \\
\hline Nasua nasua & Coati & 2 & 7 & 3 & 42.9 \\
\hline Mazama nana & Pygmy brocket & 1 & 4 & 3 & 75.0 \\
\hline Mazama gouazoubira & Gray brocket & 1 & 4 & 3 & 75.0 \\
\hline Tayassu tajacu & Collared peccary & 3 & 9 & 8 & 88.9 \\
\hline Tayassu pecari & Lipped peccary & 2 & 11 & 7 & 63.6 \\
\hline TOTAL & & 33 & 118 & 58 & 49.15 \\
\hline
\end{tabular}

Figure 2. Oocysts of Cryptosporidium spp. stained by modified Ziehl-Neelsen method observed in increased 1000X. A) Positive stool sample of Ateles paniscus for Cryptosporidium spp.; B) Positive stool sample of Amazona aestiva for Cryptosporidium spp.

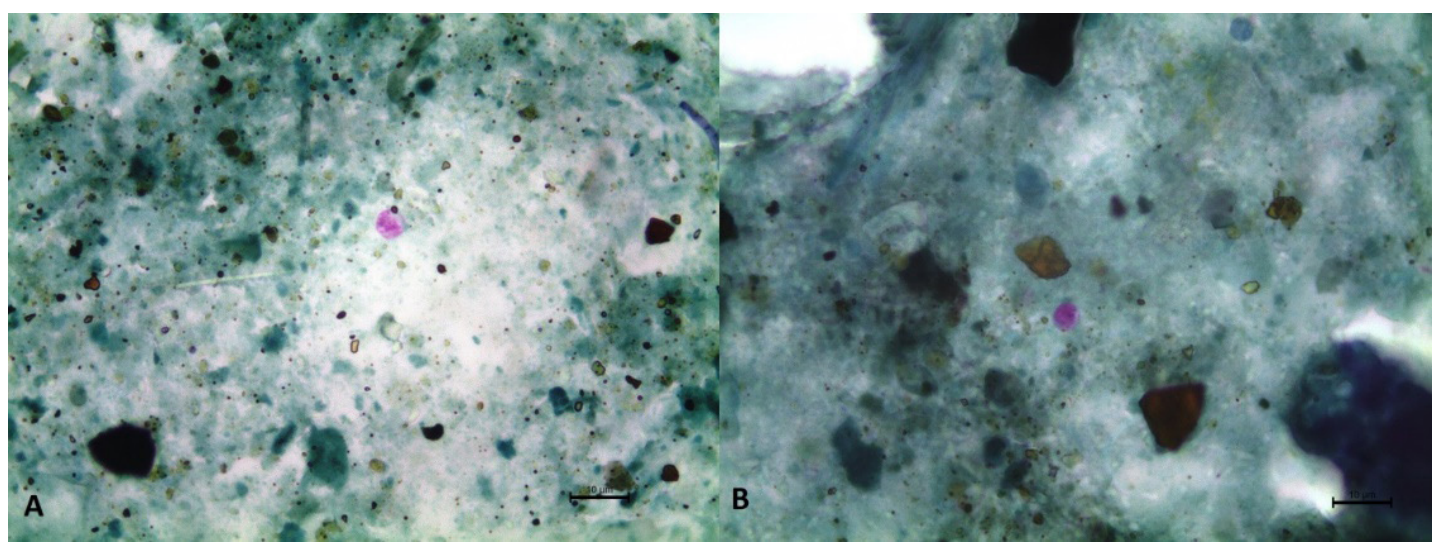


One howler stool sample was positive (20\%), much lower than the percentage found by Silva et al. (2009) found that $100 \%$ positivity for this species in a research conducted using eight howlers of Santa Maria (RS). Ludwig and Marques (2011) analyzed the feces of some animals of Porto Alegre (RS) and also found Cryptosporidium spp. in howlers' feces. Yet Kowalewski et al. (2011) analyzed 90 feces samples of free-living howlers in Argentina and all were negative for Cryptosporidium spp.

Fifty percent of Callithrix sp. (marmoset) analyzed feces were positive, positive results right above those found by Lallo and Bondan (2009) who analyzed tamarins feces of deforested areas of Sao Paulo and all samples were negative.

Six out of nine cougar's feces samples analyzed $(66.66 \%)$ found the parasite. Other authors also reported the presence of the parasite in cougar, as Fanfa et al. (2011), Cabral et al. (2001) and Ludwig and Marques (2011) in Santa Maria (RS), Uberlandia (MG) and Porto Alegre (RS) respectively.

The lipped peccaries showed high positivity in this study, similar to those found by Farret et al. (2010) in lipped peccaries in Rio Grande do Sul and Gómez et al. (2000) who analyzed feces of primates and herbivores of Barcelona Zoo, Spain, and found Cryptosporidium spp. oocytes in six primate species and 12 herbivores, among them Tayassu tajacu, these data are similar to our work, which also was found oocysts in these animals.

Oncillas showed a positivity of 50\%. Holsback et al. (2013) also found the protozoa in the same animal species in Mato Grosso do Sul and Southern Sao Paulo region.

The coati samples analyzed revealed a positivity of $42.85 \%$, Farret et al. (2008) analyzed the feces of carnivores on Rio Grande do Sul and also found Cryptosporidium spp. in coatis. The authors report that the high frequency of parasitic diseases in captive animals may be due to the constant stress which these animals are subjected, because they live outside their natural habitat.

Regarding to captive birds, out of the 65 samples collected from enclosures, 29 were positive, corresponding to $44.61 \%$ of positivity (Table 2). Sevá et al. (2011) analyzed feces of 242 wild birds in São Paulo, Brazil and found $6.6 \%$ of positive samples for Cryptosporidium sp., a number lower than what was found in this study. The highest positivity frequencies found in our study may be due to the form of collection, which was made in pool of collective places, wherein the ideal, according to Qi et al. (2011) would make the individual collection to know actual prevalence.

Table 2. Results of birds' samples of Municipal Park Danilo Galafassi processed by the Ziehl-Neelsen method.

\begin{tabular}{llccc}
\multicolumn{1}{c}{ Scientific name } & \multicolumn{1}{c}{ Common name } & Samples & Pos. & Continue ... \\
\hline Cyanoliseus patagonus & Burrowing parrot & 3 & 3 & 100 \\
Baillonius bailloni & Saffron toucanet & 1 & 1 & 100 \\
Amazona aestiva & Parrot & 2 & 2 & 100 \\
Rhea americana & Greater rhea & 4 & 3 & 75 \\
Penelope ochrogaster & Hestnut-belliend guan & 4 & 3 & 75 \\
Pavo cristatus & Indian peafowl & 4 & 2 & 50 \\
Jabiru mycteria/ Cariama cristata & Jabiru/ Red-legged seriema & 4 & 2 & 50 \\
Polyborus plancus & Caracara & 4 & 2 & 50 \\
Ara ararauna & Blue-and-yellow macaw & 4 & 2 & 50 \\
Pionus maximiliani & Scaly-headed parrot & 6 & 3 & 50 \\
Pteroglossus castanotis & Chestnut-eared aracari & 3 & 1 & 33.3 \\
\hline
\end{tabular}




\begin{tabular}{llllc}
\hline Tyto alba & Barn owl & 4 & 1 & 25 \\
Ramphastos dicolorus & Green-billed toucan & 4 & 1 & 25 \\
Ciconia maguari & Maguari stork & 4 & 1 & 25 \\
Rhinoptynx clamator & Striped owl & 2 & 0 & 0 \\
Milvago chimachima & Yellow-headed caracara & 2 & 0 & 0 \\
Heterospiziasmeridionalis & Savanna hawk & 2 & 0 & 0 \\
Ara chloroptera & Red-and-green macaw & 2 & 0 & 0 \\
\hline TOTAL & & 65 & 29 & 44.61 \\
\hline
\end{tabular}

After measuring the oocysts with a capture microscopy, it was seen that the size ranged from $3.54 \mu \mathrm{m}$ to $5.81 \mu \mathrm{m}$, with an average size of $4.32 \mu \mathrm{m}$ (Fig 2B), which is consistent with the work of Xiao et al. (2002) in which the oocysts ranged from $3 \mu \mathrm{m}$ to $8 \mu \mathrm{m}$ in size.

The results showed a wide variation of positivity, from $100 \%$ for parrots, Saffron toucanet and Burrowing parrot, to $0 \%$ for Striped owl, Yellowheaded caracara, Savanna hawk and Red-and-green macaw. Qi et al. (2011) also conducted a work of identifying Cryptosporidium in birds and found a variation of positive results from 0 to $100 \%$, depending on the species of the bird. These authors conducted species identification and found $\mathrm{C}$. baileyi, C. meleagridis, C. avium and bird genotype.

The frequency of positivity for parrots was $73.33 \%$, a number much higher than those found by Silva et al. (2008) who conducted a survey of captive parrots in Cachoeira do Sul-RS region and found $59.17 \%$ of positivity. But when we analyze the frequency of species, we found a higher prevalence for Amazon Aesti (100\%) and lower for Ara ararraunae (50\%) when compared to the results from our work. In a study by Rohela et al. (2005) with birds of a Malaysian, zoo it found Cryptosporidium in Ara ararauna and Pavo cristatus, as well as in our work. Different results to those found in this study were reported by Rohela et al. (2005) found oocysts in stool of Ara chloroptera, which was not found in Cascavel Zoo.
When we analyzed feces of parrots, we found a positivity of 50\%, similar to Holsback et al. (2013) results, who also found Cryptosporidium spp. in samples of maritaca's feces in the State of Mato Grosso do Sul and São Paulo.

Regarding to greater rhea, Cryptosporidium spp. oocytes were found in $75 \%$ of samples analyzed. Results with lower positivity to those found in greater rheas were observed by Ludwig and Marques (2008) published the first report of Cryptosporidium $\mathrm{sp}$. in these animals in the metropolitan region of Porto Alegre, with a positivity of $33.33 \%$.

The oscillation of positive results can be due the elimination of oocysts that occurs in an intermittent way, periods only when the disease is active (immunosuppression) and usually when there is diarrhea.

This work has shown that there is a high prevalence of Cryptosporidium spp. in wild animals and how there is still no effective treatment, disease control is by preventive measures, aimed at breaking the chain of transmission, such as enclosures cleaning preventing access of other animals, oocysts research in water used for drinking, either animals as employees and visitors to the park, since water is the main route of transmission of this important zoonosis. Keepers, veterinarians and biologists should avoid direct contact with the feces of animals, use gloves to handle them and wash their hands thoroughly after the procedures done with animals. 


\section{Conclusion}

Oocysts of Cryptosporidium spp. were found in mammals, representing a $49.15 \%$ positivity. The species with the highest frequency of positivity were: Mazama nana, Mazama gouazoupira, Tayassuta guan and Cebus sp. The species Panthera onca, Panthera leo and Cerdo cyonthous were negative for the presence of the parasite.

Regarding the birds, the frequency of positive samples found was $44.61 \%$. The species showing greater occurrence were Amazona aestiva, Cyanoliseus patagonus, Baillonius bailloni, Penelope ochrogaster and Rhea americana while the species Ara chloroptera, clamator Rhinoptynx, chimachima Milvago and Heterospizias meridionalis were negative.

\section{References}

ABRAHAMSEN, M. S.; TEMPLETON, T. J.; ENOMOTO, S.; ABRAHANTE, J. E.; ZHU, G.; LANCTO, C. A.; DENG, M.; LIU, C.; WIDMER, G.; TZIPORI, S.; BUCK, G. A.; XU, P.; BANKIER, A. T.; DEAR, P. H.; KONFORTOV, B. A.; SPRIGGS, H. F.; IYER, L.; ANANTHARAMAN, V.; ARAVIND, L.; KAPUR, V. Complete genome sequence of the apicomplexan, Cryptosporidium parvum. Science, Washington, v. 304, n. 5669, p. 441-445, 2004.

ARROWOOD, M. J.; STERLING, C. R. Comparison of conventional staining methods and monoclonal antibodybased methods for Cryptosporidium oocyst detection. Journal of Clinical Microbiology, Washington, v. 27, n. 7, p. 1490-1495, 1989.

ATWILL, E. R.; SWEITZER, R. A.; PEREIRA, M. G.; GARDNER, I. A.; VAN VUREN, D.; BOYCE, W. M. Prevalence of and associated risk factors for shedding Cryptosporidium parvum oocysts and Giardia cysts within feral pig populations in California. Applied and Environmental Microbiology, Washington, v. 63, n. 10, p. 3946-3949, 1997.

CABRAL, D. D.; BARBOSA, F. C.; STRASSER, C.; BARSOTTI, S. R. H. Exame de fezes de mamíferos silvestres para verificação de parasitismo por Cryptosporidium sp. Bioscience Journal, Uberlândia, v. 17, n. 1, p. 77-83, 2001.

DU, S. Z.; ZHAO, G. H.; SHAO, J. F.; FANG, Y. Q.; TIAN, G. R.; ZHANG, L. X.; WANG, R. J.; WANG, H. Y.; QI,
M.; YU, S. K. Cryptosporidium spp., Giardia intestinalis, and Enterocytozoon bieneusi in Captive Non-Human Primates in Qinling Mountains. The Korean Journal of Parasitology, Seoul, v. 53, n. 4, p. 395-402, 2015.

EKANAYAKE, D. K.; ARULKANTHAN, A.; HORADAGODA, N. U.; SANJEEVAN, G. K. M.; KIEFT, R.; GUNATILAKE, S.; DITTUS, W. P. J. Prevalence of Cryptosporidium andother enteric parasites among wild non-human primates in Polonnaruwa, Sri Lanka. American Journal Tropical Medicine and Hygiene, Deefield, v. 74, n. 2, p. 322-329, 2006.

FANFA, V. R.; FARRET, M. H.; SILVA, A. S.; MONTEIRO, S. G. Endoparasitoses em puma (Puma concolor) na região sul do Brasil. Acta Veterinaria Brasilica, Mossoró, v. 5, n. 1, p. 100-102, 2011.

FARRET, M. H.; FANFA, V. R.; SILVA, A. S.; MONTEIRO, S. G. Protozoarios gastrointestinais em Tayassu pecari mantidos em cativeiro no Brasil. Semina: Ciências Agrárias, Londrina, v. 31, n. 4, p. 1041-1044, 2010.

FARRET, M. H.; FANFA, V. R.; SILVA,A. S.;ZANETTE, R. A.; MONTEIRO, S. G. Parasitismo por protozoários gastrointestinais em carnívoros silvestres mantidos em cativeiro no sul do Brasil. Revista Portuguesa de Ciencia Veterinaria, Lisboa, v. 103, n. 565, p. 93-95, 2008.

FAYER, R. Taxonomy and species delimitation in Cryptosporidium. Experimental Parasiology, San Diego, v. 124, n. 1, p. 90-97, 2010.

GÓMEZ, M. S.; TORRES, J.; GRACENEA, M.; FERNANDEZ-MORÁN, J.; GONZALEZ-MORENO, O. Further report on Cryptosporidium in Barcelona Zoo Mammals. Parasitology Research, Berlim, v. 86, n. 4, p. 318-323, 2000.

GOOGLE Maps. Cidade de Cascavel, Paraná, Brasil. Disponível em: <https:/www.google.com.br/maps/ place/Cascavel,+PR/@-24.9619258,-53.4524419,14z/da ta $=! 4 \mathrm{~m} 2 ! 3 \mathrm{~m} 1$ ! $1 \mathrm{~s} 0 \times$ 94f3d41 ec7f74d61:0xebac32ece05a5 $\mathrm{fbc}>$. Acesso em: 15 out. 2015.

HOLSBACK, L.; CARDOSO, M. J. L.; FAGNANIR, R.; PATELLI, T. H. C. Natural infection by endoparasites among free-living wild animals. Revista Brasileira de Parasitologia Veterinária, Jaboticabal, v. 22, n. 2, p. 302306, 2013.

KOWALEWSKI, M. M.; SALZER, J. S.; DEUTSCH, J. C.; RAÑO, M.; KUHLENSCHMIDT, M. S.; GILLESPIE, T. R. Black and gold howler monkeys (Alouatta caraya) as sentinels of ecosystem health: patterns of zoonotic protozoa infection relative to degree of human-primate contact. American Journal Primatology, Malden, v. 73, n. 1, p. $75-83,2011$. 
LALlO, M. A.; BONDAN, E. F. Prevalência de Cryptosporidium sp. em cães de instituições da cidade de São Paulo. Revista de Saúde Pública, São Paulo, v. 40, n. 1, p. 120-125, 2009.

LI, N.; ALDERISIO, K.; ELWIN, K.; CEBELINSKI, E.; CHALMARS, R.; SANTIN, M.; FAYER, R.; KVAC, M.; RYAN, U.; SAK, B.; STANKO, M.; GUO, Y.; WANG, L.; ZHANG, L.; CAI, J.; ROELLING, D.; FENG, Y. Subtyping Cryptosporidium ubiquitum, a zoonotic pathogenemerging in humans. Emerging Infectous Disseases, Atlanta, v. 20, n. 2, p. 217-224, 2014.

LUDWIG, R.; MARQUES, S. M. T. Occurrence of Cryptosporidium spp. oocysts in mammals at a zoo in southern Brazil. Revista Ibero-Latinoamericana de Parasitologia, Santiago, v. 70, n. 1, p. 122-128, 2011.

ORTOLANI, E. L. Standardization of the modified ZiehlNeelsen technique to stain oocysts of Cryptosporidium sp. Revista Brasileira de Parasitologia Veterinária, Jaboticabal, v. 9, n. 1, p. 29-31, 2000.

PARSONS, M. B.; TRAVIS, D.; LONSDORF, E. V.; LIPENDE, I.; ROELLIG, D. M.; COLLINS, A.; KAMENYA, S.; ZHANG, H., XIAO, L.; GILLESPIE, T. R. Epidemiology and molecular characterization of Cryptosporidium spp. in humans, wild primates, and domesticated animals in the Greater Gombe Ecosystem, Tanzania. PLoS Neglected Tropical Diseases, California, v. 9 , n. 2, p. 1-13, 2015.

PEREIRA, M. G. C.; LI, X.; MCCOWAN, B.; PHILLIPS, R. L.; ATWILL, E. R. Multiple unique Cryptosporidium isolates from three species of ground squirrels ( $S$ permophilus beecheyi, S. beldingiand, S. lateralis) in California. Applied and Environmental Microbiology, Washington, v. 76, n. 24, p. 8269-8276, 2010.

PORTAL do Município de Cascavel. Parques. Cascavel: Prefeitura Municipal de Cascavel, 2010. Disponível em: $<$ http://www.cascavel.pr.gov.br/secretarias/semdec/sub_ pagina.php?id=258>. Acesso em: 15 out. 2015.

QI, M.; WANG, R.; NING, C.; LI, X.; ZHANG, L.; JIAN, F.; SUN, Y.; XIAO, L. Cryptosporidium spp. in pet birds: genetic diversity and potential public health significance. Experimental Parasiology, San Diego, v. 128, n. 4, p. 336-40, 2011.

ROHELA, M.; LIM, Y. A. L.; JAMAIAH, I.; KHADIJAH, P. Y. Y.; LAANG, S. T.; MOHDNAZRI, M. H.; NURULHUDA, Z. Occurrence of Cryptosporidium oocysts in wrinkled hornbill and other birds in the Kuala Lumpur National Zoo. The Southeast Asian Journal of Tropical Medicine and Public Health, Bancoque, v. 36, n. 4, p. 34-40, 2005.
RYAN, U.; FAYER, R.; XIAO, L. Cryptosporidium species in humans and animals: current understanding and research needs. Parasitology, Cambridge, v. 141, n. 13, p. 1667-1685, 2014.

SAK, B.; PETRZILKOVA, K. J.; KVETONOVA, D.; MYNAROVA, A.; SHUTT, K. A.; POMAJBIKOVA, K.; KALOUSOVA, B.; MODRY, D.; BENAVIDES, J.; TODD, A.; KVAC, M. Long-term monitoring of microsporidia, Cryptosporidium and Giardia infections in western Lowland Gorillas (Gorilla gorilla gorilla) at different stages of habituation in Dzanga Sangha Protected Areas, Central African Republic. PLoS One, San Francisco, v. 7, n. 8, p. 1-10, 2013.

SALYER, S. J.; GILLESPIE, T. R.; RWEGO, I. B.; CHAPMAN, C. A.; GOLDBERG, T. L. Epidemiology and molecular relationships of Cryptosporidium spp. in people, primates, and livestock from Western Uganda. PLoS Neglected Tropical Diseases, California, v. 6, n. 4, p. 1-6, 2012.

SANTÍN, M. Clinical and subclinical infections with Cryptosporidium in animals. New Zealand Veterinary Jounal, Palmerston North, v. 61, n. 1, p. 1-10, 2013.

SAVIOLI, L.; SMITH, H.; THOMPSON, A. Giardia and Cryptosporidium join the 'Neglected Diseases Initiative'. Trends in Parasitology, Cambridge, v. 22, n. 5, p. 203208, 2006.

SEVÁ, A. P.; FUNADA, M. R.; RICHTZENHAIN, L.; GUIMARÃES, M. B.; SOUZA, S. L.; ALLEGRETTI, L.; SINHORINI, J. U. A.; DUARTE, V. V.; SOARES, R. M. Genotyping of Cryptosporidium spp. From freeliving wild birds from Brazil. Veterinary Parasitology, Liverpool, v. 175, n. 1-2, p. 27-32, 2011.

SILVA, A. S.; GRESSLER, L. T.; LARA, V. M.; MONTEIRO, S. G.; CARREGARO, A. B. Protozoários gastrintestinais em bugios (Alouatta sp.) mantidos em cativeiro. Ciência Animal Brasileira, Goiânia, v. 10, n. 2, p. 669-672, 2009.

SILVA, A. S.; MONTEIRO, S. G.; SILVA, M. K.; SOARES, J. F.; OLIVEIRA, C. B.; LIMA, F. P.; ZANETTE, A. R.; SOUZA, C. P.; SALOMÃO, E. L. Parasitismo por Cryptosporidium spp. em psitacídeos mantidos em cativeiro no município de Cachoeira do Sul - RS, Brasil. Veterinária e Zootecnia, Botucatu, v. 15, n. 2, p. 234-338, 2008.

SHI, K., JIAN, F.; LV, C.; NING, C.; ZHANG, L.; REN, X.; DEAREN, T. K.; LI, N.; QI, M.; XIAO, L. Prevalence, genetic characteristics, and zoonotic potencial of Cryptosporidium species causing infections in farm rabbits in China. Journal of Clinical Microbiolology, Washington, v. 48, n. 9, p. 3263-3266, 2010. 
XIAO, L.; FAYER, R.; RYAN, U.; STEVE, J. Cryptosporidium taxonomy: recent advances and implications for public health. Clinical Microbiology Reviews, Washington, v. 17, n. 1, p. 72-97, 2004.

XIAO, L.; SULAIMAN, I. M.; RYAN, U. M.; ZHOU, L.; ATWILL, E. R.; TISCHLER, M. L.; ZHANG, X.; FAYER, R.; LAL, A. A. Host adaptation and hostparasite co-evolution in Cryptosporidium: implications for taxonomy and public health. International Journal for Parasitology, Sidney, v. 32, n. 14, p. 1773-1785, 2002.
WANG, T.; CHEN, Z.; XIE, Y.; HOU, R.; WU, Q.; GU, X.; LAI, W.; PENG, X.; YANG, L. Prevalence and molecular characterization of Cryptosporidium in giant panda (Ailuropoda melanoleuca) in Sichuan province, China. Parasites \& Vectors, Londres, v. 8, n. 344, p. 1-5, 2015.

WANG, R.; WANG, J.; SUN, M.; DANG, H.; FENG, Y.; NING, C.; JIAN, F.; ZHANG, L.; XIAO, L. Molecular characterization of the Cryptosporidium cervine genotype from a sika deer (Cervus nippon Temminck) in Zhengzhou, China and literature review. Parasitology Research, Berlim, v. 103, n. 4, p. 865-869, 2008. 
